\title{
Journeys in Bhutan: Discussion
}

\section{Author(s): James Bourdillon, Ronald Macdonald and A. W. Paul}

Source: The Geographical Journal, Vol. 35, No. 1 (Jan., 1910), pp. 40-42

Published by: geographicalj

Stable URL: http://www.jstor.org/stable/1777116

Accessed: 27-06-2016 08:15 UTC

\section{Your use of the JSTOR archive indicates your acceptance of the Terms \& Conditions of Use, available at}

http://about.jstor.org/terms

JSTOR is a not-for-profit service that helps scholars, researchers, and students discover, use, and build upon a wide range of content in a trusted digital archive. We use information technology and tools to increase productivity and facilitate new forms of scholarship. For more information about JSTOR, please contact support@jstor.org.

The Royal Geographical Society (with the Institute of British Geographers), Wiley are collaborating with JSTOR to digitize, preserve and extend access to The Geographical Journal 
which also grows wild. No attempt has been made to grow mulberry plants, because the cocoons, from which Endi or Erhi or Tussar silk is made, are collected in their wild state from the jungles inhabited by the insects which produce them.

The President (before the paper): Mr. White, who has kindly consented to lecture here to-night, is an engineer by profession, and, in the course of his professional duties, he has visited a great many parts of India. During the last twenty years he has been chiefly employed in Sikkim and in connection with the Tibeian border, and he has thus had the opportunity of making a number of interesting journeys into Bhutan, a region which is very little known. It is the results of those journeys which he is kindly going to describe to us to-night.

After the paper, Sir JAMES Bourdillon: I was not aware that any discussion would take place, but I should like to say a few words which occur to me with reference to Mr. White's lecture. I wish first to draw attention to a matter. which would certainly never have been mentioned by Mr. White himself, and that is the great debt we all owe to his untiring endeavours, and to his personal qualifications for carrying out the expedition he has described. He was stationed for a long time in the Eastern Himalayas, and gradually acquired a unique influence and authority among the people of those regions. Thus has grown up gradually, and by almost imperceptible degrees, the great power he displayed in carrying through this expedition. Bhutan, for a long time, has been an absolutely closed country to Europeans, and, if we look back to our official relations with that country, the review is one which cannot be regarded with satisfaction. Our envoys have been insulted, and our efforts towards friendship hàve been frustrated again and again; so that it is a most remarkable achievement on Mr. White's part that he has been able to carry out this expedition, and to turn what was a hostile foreign state into a neighbour closely allied in friendship with the Government of India. Mr. White has not been able, in the short time placed at his disposal this evening, to say much about the manufactures and the beautiful artistic work accomplished by the people. 'The Bhutanese have long enjoyed a very remarkable civilization. The metal work, the weaving, the embroidery, are all of the highest character, and not only very beautiful, but possessed of very distinct characteristics of their own. In conclusion, I will only ask you to express your satisfaction with the lecture we have heard to-night, and in doing so, never to forget how much is due to the great personal influence of Mr. White himself.

General Sir Ronald Macdonald: My first acquaintance with Mr. White was just at the start of the Tibet Expedition. I had then the feeling that trusting to a single line was perhaps rather hazardous, and I asked Mr. White whether he could run an alternative line from Siklim. He at once undertook to do so, and, thanks to his influence in Sikkim, he was able to put on something like $1500 \mathrm{men}$, who worked all through the winter and assisted our advance. When we got into the Chumbi valley in the winter, we very soon found that Mr. White had a great reputation among the Bhutanese, and when the Tongsa penlop, who is now the Mabarajah Bhutan, came to visit us, he was already predisposed in Mr. White's favour; bat this rapidly ripened into confidence and friendship, which has enabled Mr. White to achieve the great results of which we have just heard. We have heard how Mr. White was a welcome and honoured visitor in the exclusive country of Bhutan, and I will mention one little incident at Lhasa. When we arrived there, the Tibetan representatives asked us that we should prevent any of our officers or men entering any of their sacred places. After consulting Colonel Younghusband 
I issued orders that all monasteries and temples were to be out of bounds. Then a message came in from the monasteries and chief Llamas to say that $\mathrm{Mr}$. White was expressly excluded from this restriction, as he was welcome to visit their monasteries at any time, and they would be glad to see with him any officers for whom be vouched. While Younghusband and I were debarred from vis:ting any of these places, Mr. White was welcome.

Mr. A. W. PAUL: I may be permitted to add a few words to Mr. White's lecture, as I accompanied him in one of his journeys, and I would emphasize in particular the kindly way in which we were treated. I had some slight acquaintance with the Bhutanese before, because they were always having revolutions, and the unsuccessful always came to me, but even I did not realize their true worth When I went under Mr. White's auspices, I was practically a cripple. They understood that, and I was met by all sorts of contrivances to get me through without trouble. On the last pass I had two yaks, because they said the yaks were not in very good condition owing to the severe winter, and might get tired and jerk me; I had three mules-the very best, and, what was more than all this, five stalwart men. Mr. White only told you half the truth when he said that for dignity's sake he rode up from the river to the Tongsar fort. I can only tell you that not even his cook was able to ride down to the river. When I started I did not know what I was going to do, but I found my five men waiting for me, and they got me over that awful place in comparative comfort; it did not matter in the least bit where I was, I always had somebody to help me. I can only join with Mr. White in thanking them sincerely for all the kindness they have shown us. I quite endorse every word that has been said about Mr. White's influence and about the necessity of knowing more about Bhutan. 'The difficulty, even in recent years, of getting into touch with Bhutan and learning the true position of affairs there, was a cause both of anxiety and danger. Even as late as February, 1874, Mr. (Sir John) Edgar, then Deputy Commissioner of Darjeeling, wrote to me, "I have been thinking about that Bhutan business, and do not like it. I do not see clearly any danger on our side, but still one ought to make sure. Make private inquiries, but mind there is no fuss, for of course very little would make a panic, which of all things is to be avoided." It was essential to do everything possible to prevent a panic taking place amongst the coolies on the all-important tea districts lying at the foot of the Bhutanese hills.

It was a work of constant and unceasing anxiety to get into closer relations with Bhutan, all the more difficult because Government did not give us a free hand. But now Mr. White has changed all this, and the Bhlitanese officials, so far from resenting interference, voluntarily petitioned Government to grant Mr. White extension of service that be might continue to help them.

Since Bhutan is so near the wealthy plains covered with tea gardens, it is absolutely necessary for the Government to encourage Mr. White's successor to continue amicable and sympathetic feeling and intercourse with the people of Bhutan, so that we may be confident that nothing will disturb the progress of the great tea industry. I am sure you will join in thanking $\mathrm{Mr}$. White for having opened up a country which was described once as " hardly worthy of much consideration."

The President: In bringing the discussion to a close after the extremely interesting paper which Mr. White has been kind enough to read to us, I am speaking in the name of everybody here present when I say that the photographs have been ones of exceptional interest and exceptional beauty. I am very glad to hear what has been said by the various authorities here present of Mr. White's admirable work in Bhutan, and I am sure he deserves the greatest credit for what he has done in creating a spirit of friendship between the people of Bhutan and the 
people of England. Mr. White tells me that he was able on one or two occasions to do a certain amount of surveying. It is often impossible for the head of an expedition to spend very much time in surveying operations, and I cannot help feeling it is a pity that the Government of India does not send a trained surveyor with all such expeditions. If this had been done we should now know far more about the detailed geography of Bhutan. The Government and people of this country are very apt to cry out for the want of maps. But if such steps were taken in advance, then the information would be at hand when wanted. I have merely to add that we always have an exhibition of objects of interest from the country about which the paper deals, and that on this occasion it is one of exceptional interest.

\section{THE DEVELOPMENT OF WHEAT CULTURE IN NORTH AMERICA.*}

\section{By ALBERT PERRY BRIGHAM.}

IN the year 1602, on one of the Elizabeth islands off the present coast of Massachusetts, Bartholomew Gosnold made trial plantings of wheat and other grains. The Spaniards had earlier brought wheat to Mexico, but this was probably the first wheat sown within the boundaries of the United States. Nearly twenty years later wheat was sown at Plymouth, without success the first season, but with returns afterward. The grain extended itself among the New England colonies, and about 1700 there are records of shipments, as from Norwalk to Boston and Boston to Virginia. As the eighteenth century progressed, however, wheat declined, except as sown on fresh clearings, and was brought in from New York and the southern colonies. That wheat was already moving westward is shown by the fact that New England traders bought New York wheat, ground it in their own mills, and sold it in the West Indies. To revive wheat culture, Massachusetts laid a duty on the product to be paid as a bounty to farmers, but Weeden tersely says that "the duty could not counteract climate and soil nor feed the fishermen."

There is early record of wheat in Virginia, for in 1607 the Council informed the Council in England that they had fortified themselves against Indians and had "sown good store of wheat." The first sowings of English 'seed at Jamestown seem not to have been very successful. By 1800 wheat was raised along the entire Atlantic border except the southern parts of the coastal plain, but the middle states from New York to Virginia assumed pre-eminence and held the centre of wheat for more than a generation. Meantime, in 1769 , missionaries carried the grain to California. There was important export to the West Indies in the early years of the Federal government, until Great Britain shut out the ships of the United States from this trade. In 1787 wheat was among American exports to Mauritius. But it was long before the United States was to assume a commanding position as a purveyor of bread, for in the decade 1830-1840 she imported several million bushels of wheat to feed her own population.

In the later years of the eighteenth century and the first decades of the nineteenth, western New York, or the Genesee country, proved its suitability in soil and climate for the growing of winter wheat. On the completion of the Erie canal in 1825 , the industry was favoured by increased prices; the region was the famous wheat centre of the country, and Rochester was relatively as important for primary market

* Read at a joint meeting of the Sections of Geography, Agriculture, and Economics, British Association, Winnipeg, August, 1909. 